But the study concludes on an optimistic note. International aid agencies and politicians in developing countries are becoming more aware of the need to protect and manage forests. And the dismal record of tree planting in the third world--millions of young trees uprooted or nibbled to death by livestock-is showing signs of improvement in places where the "community forestry" approach is adopted. This means giving villagers the means to meet their own requirements and protect their own growing trees, Eckholm says, rather than imposing planting programmes in which they have no sayas has happened too often in the past.

The astonishing success of forestry in post-revolutionary China is the best known example of this philosophy. But Eckholm says the "success story of the 1970's" is South Korea. There a

\title{
A day in the life of Yurii Orlov
}

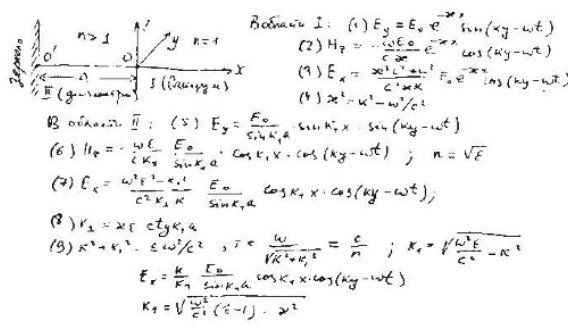

A jailed dissident is keeping up his scientific work in a Soviet labour camp.

\section{Vera Rich reports}

Yurii Orlov, founder-member of the Moscow Helsinki monitoring group, was arrested two years ago this month. Unlike Academician Andrei Sakharov, who has virtually given up scientific work to devote himself to human rights, Dr Orlov, until the moment of his arrest, considered himself a scientist. Indeed, his letters from prison (which reached Nature recently) indicate that he is still attempting to pursue his research.

Until his trial last May, Orlov was held incommunicado. After his trial he was permitted to write the usual two letters per month, and immediately began to request writing materials and scientific texts. "I'd like to have Landau's quantum mechanics", he wrote to his wife in July, "it's lying on the shelf".

In the same letter he reports on his work in progress. "I'm constantly doing scientific calculations.

As you know, I've already completely finished one paper on logic, when I've copied it out, I shall send it officially to the Landau Institute of Theoretical Physics, to the Director."

However, two papers written during his pre-trial confinement had been confiscated. The next letter suggests, obliquely, that he was contemplating a hunger-strike if they were not returned.

Three weeks later, he was still anxious about the fate of these papers, and further perturbed that his paper on logic had not reached the director of the Landau Institute. But a long postscript to be passed on to his scientific friends outlined his latest train of thought. "While I was in quarantine, I did a small calculation for myself. I considered whether it was possible, by passing a beam of light along a wave-guide (i.e. with total internal reflection), to obtain beyond the limits of the wave-guide, in vacuo, an electromagnetic wave extended to a fairly great distance."

But the conditions for such quiet scientific reflection had already come to an end. In mid-August, Orlov had been transferred to a labour-camp where he found himself doing heavy physical work at an altitude of more than $1,000 \mathrm{~m}$ which left him completely incapable of any serious scientific activity.

By mid-October, when he had moved to another camp, No. 37, his letters once again show interest in scientific matters. One letter deals almost entirely with problems of cybernetics and his concept of "wave logic". There are interesting references to past discussions with Gol'fand, Rozenshtein-presumably within the framework of the refusniks' "Sunday seminars" of which Orlov was one of the few nonJewish members.

But his conditions of work were still those of hard labour. "I'm working in the plant all week now. I had a choice: cutter or turner. The cutting shop makes a great deal of noise; in the turning shop you have to keep spinning around. I chose the turning shop. I'm still a learner: how it is possible to fulfil one's norm, I still can't imagine. ..."

Yurii Orlov has seven years to serve in the labour camp, plus five years "internal exile". The avowed purpose of work in a labour camp is rehabilitation through service to the community. In almost every respect, conditions for political prisoners have improved considerably in the 25 years since Stalin's death. The one exception is that of scientists. As Orlov's friend, who forwarded the letters to Nature pointed out: "In Stalin's time, scientistnrisoners did research in special prison laboratories - Solzhenitsyn's First Circle. They didn't have to waste their talents in physical labour, as Orlov does". strong national commitment, combined with new village-level forestry associations, has covered one-third of the country with trees in the past decade and nearly solved an acute firewood crisis.

Worldwatch Paper 26, 'Planting for the Future: Forestry for Human Needs', is published by the Worldwatch Institute, Washington $D C$, at $\$ 2$.

\section{Soviets seek US collaboration over biosatellite}

Soviex space biologists have invited their US opposite numbers to take part in the experimental programme for the next Soviet bio-satellite scheduled for the end of 1979 .

This proposed venture was announced by Dr Nikola Gurovskii, a leading member of the Soviet team shortly before a new agreement was signed extending cooperation between the Academies of the two countries. Much of the agreement dealt with details of exchange visits (up to 100 personmonths per year) and research visits (16 from each side per year of from 3 to 12 person-month). However, there was also a general acceptance of the desirability of using the new agreement to place greater emphasis on cooperative activities, dealing with important scientific problems-a slot which would neatly take in the bio-satellite.

Dr Gurovskii said that this satellite would include 13 joint experiments. For the first time, the effect of weightlessness on mammals (rats) and birds (quails) would be investigated. There would be further investigations of the physiological effects of space-flight, and also tests on a new "antiradiation" medicine, using dosimeters manufactured in the US.

These latter aspects are of particular interest to Soviet space medicine, according to a recent article in Pravda by Dr Avetik Burnazyan. He stated that the decisive factor limiting spaceflights is no longer a technical one, but the ability of the organism to re-adapt to Earth conditions.

The proposed joint biosatellite programme will not be the first time there has been such cooperation; similar though less ambitious joint programmes were carried out on the Kosmos-782 and -936 satellites.

In Dr Gurovskii's opinion, however, the extension of such cooperation is of major importance. It is becoming ever more difficult, he said, to develop science in a "narrow national framework". For "truly outstanding results", international cooperation is essential.

Vera Rich 